\title{
Profil Penguasaan Konsep Siswa SMA pada Materi Suhu dan Kalor
}

\author{
Ina Yuliana ${ }^{1}$, Sentot Kusairi ${ }^{1}$, Ahmad Taufiq ${ }^{1}$ \\ ${ }^{1}$ Pendidikan Fisika-Universitas Negeri Malang
}

\begin{tabular}{l}
\hline \hline INFO ARTIKEL \\
\hline Riwayat Artikel: \\
Diterima: 08-02-2019 \\
Disetujui: 22-05-2019 \\
\hline
\end{tabular}

\section{Kata kunci:}

mastery of concepts; temperature;

heat;

penguasaan konsep;

suhu;

kalor

\begin{abstract}
ABSTRAK
Abstract: This study purpose to describe students' conceptual mastery and knowing the students' difficulties understanding on heat and temperature. This survey research was conducted on $11^{\text {th }}$ grade of mathematic and natural science class in senior high school students. Data was obtained through reasoned multiple choice questions of conceptual mastery. We found that only $54.8 \%$ of students had good conceptual mastery. This shows that students' conceptual mastery is low on heat and temperature. In addition, we found three student's difficulties, namely: (1) cannot distinguish definition of heat and temperature, (2) don't know factors that can affect temperature changes and phase changes, and (3) unable to solve heat transfer problem. It is expected that future study can improve students' conceptual mastery through application of appropriate learnings.
\end{abstract}

\begin{abstract}
Abstrak: Penelitian ini bertujuan mendeskripsikan profil penguasaan konsep siswa dan mengetahui kesulitan-kesulitan yang dialami oleh siswa pada materi suhu dan kalor. Penelitian survei ini dilakukan pada siswa kelas XI SMA MIPA. Data diperoleh melalui tes penguasaan konsep berupa soal pilihan ganda beralasan. Kami menemukan bahwa hanya 54.8\% siswa yang memiliki penguasaan konsep yang baik. Hal ini menunjukkan bahwa penguasaan konsep suhu dan kalor siswa masih rendah. Selain itu, kami menemukan tiga kesulitan siswa, yaitu (1) tidak bisa membedakan definisi suhu dan kalor, (2) tidak mengetahui faktor-faktor yang dapat mempengaruhi perubahan suhu dan perubahan wujud, dan (3) tidak mampu menyelesaikan permasalahan perpindahan kalor. Diharapkan kepada peneliti selanjutnya dapat memperbaiki penguasaan konsep siswa melalui penerapan pembelajaran yang sesuai.
\end{abstract}

\author{
Alamat Korespondensi: \\ Ina Yuliana \\ Pendidikan Fisika \\ Universitas Negeri Malang \\ Jalan Semarang 5 Malang \\ E-mail: inayulianaikhsan@gmail.com
}

Fisika merupakan salah satu pelajaran yang diajarkan pada tingkat sekolah menengah. Kebanyakan siswa tidak mampu memahami konsep dengan baik sehingga mengalami kesulitan saat memahami materi fisika (Gurcay \& Gulbas, 2015). Hal ini dikarenakan terdapat beberapa konsep fisika yang hanya teramati melalui fenomena-fenomenanya (Baser, 2006; Kartal et al., 2011; Madu \& Orji, 2015). Salah satu materi fisika yang dianggap sulit dipahami oleh siswa adalah materi suhu dan kalor. Suhu dan kalor merupakan salah satu materi yang memiliki konsep-konsep yang saling berkaitan dan paling umum ditemukan miskonsepsi (Ergin \& Atasoy, 2013). Fenomomena terkait materi suhu dan kalor banyak ditemukan dalam kehidupan seharihari, namun siswa masih mengalami kesulitan dalam memahaminya (Thomaz et al., 1995).

Penelitian sebelumnya mengungkapkan bahwa kesulitan yang dialami siswa pada materi suhu dan kalor adalah siswa tidak dapat membedakan antara definisi suhu dan kalor (Alwan, 2011; Fitzallen et al., 2016; Foroushani, 2018; Kruatong et al., 2006). Siswa beranggapan bahwa ketika suatu benda mengalami perubahan wujud, maka benda tersebut juga mengalami perubahan suhu (Maunah, 2014). Selain itu, siswa juga beranggapan bahwa ukuran benda dapat mempengaruhi suhu benda tersebut (Budiarti et al., 2017; de Berg, 2008; Gönen \& Kokaya, 2010).

Salah satu hal penting yang perlu dimiliki siswa untuk mengatasi kesulitan-kesulitan tersebut adalah memperbaiki penguasaan konsep siswa. Hal ini dikarenakan penguasaan konsep yang baik dapat memperbaiki pengetahuan siswa terhadap konsep fisika. Pengetahuan siswa akan berkembang apabila penguasaan konsep siswa semakin luas (Singh \& Schunn, 2010). Penguasaan konsep yang baik dapat membantu meminimalisir miskonsepsi siswa pada suatu konsep ilmu (Eraikhuemen \& Ogumogu, 2014; Ergin, 2016) dan membantu siswa dalam menyelesaikan permasalahan dengan baik (Docktor \& Mestre, 2014; Sahin, 2010).

Terdapat beberapa kendala yang mengakibatkan kesulitan siswa dalam memahami konsep suhu dan kalor, diantaranya adalah penguasaan konsep yang dimiliki siswa tentang suhu dan kalor masih terdapat beberapa yang tumpang tindih (de Berg, 2008). Penguasaan konsep suhu dan kalor siswa juga masih tergolong rendah, hal ini disebabkan karena siswa lebih cendrung 
menghafal rumus-rumus yang ada daripada memahami konsep dengan benar (Budiarti et al., 2017; Kulkarni \& Tambade, 2013). Selain itu, Cock (2012) juga mengungkapkan bahwa kemampuan siswa dalam memecahkan permasalahan fisika secara matematis tidak menjadi ukuran siswa tersebut dapat menerapkan konsep fisika dengan benar.

Berdasarkan kajian-kajian tersebut, siswa sering mengalami kesulitan dalam menyelesaikan permasalahan suhu dan kalor, sehingga perlu adanya penelitian untuk menganalisis profil penguasaan konsep suhu dan kalor siswa, sehingga guru dapat mendesain pembelajar yang dapat memperbaiki penguasaan konsep siswa. Oleh karena itu, penelitian ini bertujuan untuk mendeskripsikan profil penguasaan konsep yang dimiliki oleh siswa SMA pada materi suhu dan kalor dan mengungkap kesulitan-kesulitan yang dialami oleh siswa.

\section{METODE}

Metode yang digunakan pada penelitian ini adalah metode survei yang dilakukan pada siswa kelas XI MIPA 1. Data diperoleh melalui tes penguasaan konsep berbentuk soal pilihan ganda beralasan sebanyak 13 butir soal. Jawaban siswa kemudian dianalisis menggunakan rubrik penilaian dengan tiga kriteria penilaian, yaitu $0=$ jika tidak ada jawaban atau jawaban dan alasan salah, 1 = jika salah satu jawaban atau alasan benar, dan 2 = jika jawaban dan alasan benar (Bayrak, 2013). Penguasaan konsep yang diukur, meliputi Understanding (C2), Applying (C3), Analyzing (C4), dan Evaluating (C5). Indikator butir soal dan sebaran soal tes penguasaan konsep siswa ditunjukkan pada tabel 1.

Tabel 1. Indikator dan Sebaran Soal Tes Penguasaan Konsep Siswa

\begin{tabular}{|c|c|c|c|c|c|c|}
\hline \multirow{2}{*}{ Indikator Butir Soal } & \multirow{2}{*}{$\begin{array}{l}\text { Nomor } \\
\text { Soal }\end{array}$} & \multicolumn{5}{|c|}{ Tingkatan Kognisi } \\
\hline & & C1 & $\mathbf{C 2}$ & $\mathbf{C 3}$ & $\mathbf{C 4}$ & $\mathbf{C 5}$ \\
\hline Menjelaskan konsep perpindahan kalor pada dua benda yang berbeda jenis. & 1 & & $\sqrt{ }$ & & & \\
\hline $\begin{array}{l}\text { Menghitung skala termometer yang satu melalui skala hasil pengukuran termometer yang } \\
\text { lainnya. }\end{array}$ & 2 & & & $\sqrt{ }$ & & \\
\hline Menghitung perubahan suhu dan perubahan ukuran suatu benda ketika mengalami pemuaian. & 3 & & & $\sqrt{ }$ & & \\
\hline Menerapkan prinsip pemuaian dalam kehidupan sehari-hari. & 4 & & & $\sqrt{ }$ & & \\
\hline Menghitung jumlah kalor yang dibutuhkan suatu zat untuk dapat mengubah suhu dan wujud. & 5 & & & $\sqrt{ }$ & & \\
\hline Menganalisis pengaruh kalor jenis terhadap suhu suatu benda. & 6 & & & & $\sqrt{ }$ & \\
\hline $\begin{array}{l}\text { Menghitung besarnya kalor yang diserap suatu benda berdasarkan grafik suhu terhadap waktu } \\
\text { (T-t). }\end{array}$ & 7 & & & $\sqrt{ }$ & & \\
\hline Menerapkan konsep Asas Black pada peristiwa pencampuran dua zat yang berbeda. & 8,9 & & & $\sqrt{ }$ & & \\
\hline Menganalisis pengaruh kalor terhadap perubahan suhu dan perubahan wujud suatu benda. & 10 & & & & $\sqrt{ }$ & \\
\hline Menghitung kalor total yang dibutuhkan suatu benda untuk merubah suhu dan wujudnya. & 11 & & & $\sqrt{ }$ & & \\
\hline Membedakan perpindahan kalor secara konduksi, konveksi dan radiasi. & 12 & & $\sqrt{ }$ & & & \\
\hline $\begin{array}{l}\text { Membandingkan besar konduktivitas dua buah benda terhadap suhu campuran setelah } \\
\text { disambung. }\end{array}$ & 13 & & & & & $\sqrt{ }$ \\
\hline
\end{tabular}

\section{HASIL}

Data pada penelitian diperoleh dari hasil test penguasaan konsep siswa pada materi suhu dan kalor. Hasil analisis persentase rata-rata skor penguasaan konsep siswa yang menjawab benar pada setiap butir soal ditunjukkan pada gambar 1 .

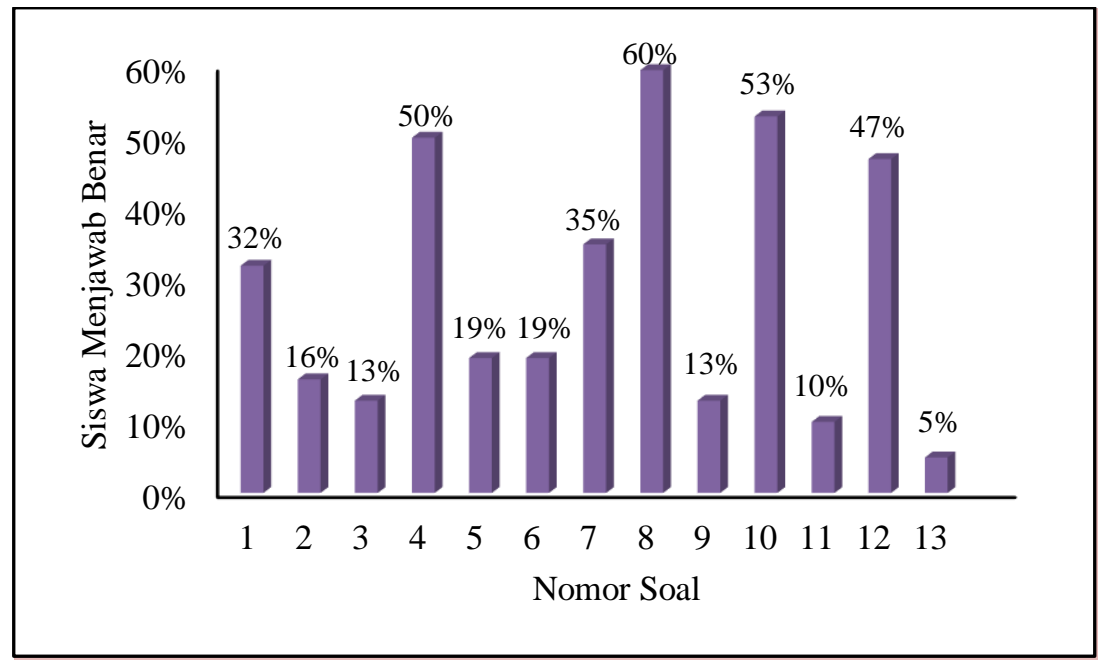

Gambar 1. Persentase Siswa yang Menjawab Benar pada Setiap Butir Soal 
Gambar 1 menunjukkan bahwa persentase skor penguasaan konsep siswa yang menjawab benar tertinggi terletak pada soal nomor 4,8, dan 10. Ketiga soal tersebut merupakan soal tentang suhu dan pemuaian, asas Black, dan perubahan wujud dengan persentase siswa yang menjawab benar berturut-turut sebesar 50\%, 60\%, dan 53\%. Sedangkan nilai persentase skor penguasaan konsep siswa yang menjawab benar terendah terletak pada soal nomor 3, 9, 11 dan 13. Keempat soal tersebut merupakan soal tentang suhu dan pemuaian, asas Black, perubahan wujud, dan perpindahan kalor dengan persentase siswa yang yang menjawab benar berturut-turut sebesar 13\%, 13\%, 10\%, dan 5\%.

Berikut ini disajikan 5 soal dari 13 soal yang digunakan pada penelitian ini yang merupakan soal dominan siswa mengalami kesulitan dalam memahaminya serta jumlah persentase pilihan jawaban siswa. Soal nomor 1 merupakan soal tentang perpindahan kalor, soal nomor 6 tentang faktor yang dapat mempengaruhi perubahan suhu benda, soal nomor 9 tentang asas Black, soal nomor 11 tentang perubahan wujud benda, dan soal nomor 13 merupakan soal tentang perpindahan kalor.

1. Dua batang logam $X$ dan $Y$ memiliki massa yang sama. Batang logam $Y$ memiliki suhu lebih tinggi dari batang logam $\mathrm{X}$. Jika kedua batang logam disentuhkan, maka...
A. kalor berpindah dari $\mathrm{X}$ ke $\mathrm{Y}$
$0(0 \%)$
B. kalor berpindah dari $\mathrm{Y}$ ke $\mathrm{X}^{*}$
$13(41,94 \%)$
C. suhu berpindah dari $\mathrm{X}$ ke $\mathrm{Y}$
$0(0 \%)$
D. suhu berpindah dari $Y$ ke $X$
$4(12,90 \%)$
E. suhu dan kalor berpindah dari $\mathrm{Y}$ ke $\mathrm{X}$
$14(45,16 \%)$
Tidak menjawab
$0(0 \%)$

Berdasarkan soal nomor 1, diperoleh bahwa dari 31 siswa terdapat 13 siswa yang menjawab opsi B, 4 siswa yang menjawab opsi D, 14 siswa yang menjawab opsi E, dan tidak ada siswa yang menjawab opsi A dan C. Hal ini menunjukkan bahwa dominan siswa memilih opsi E yang merupakan jawaban yang salah dengan persentase sebesar 45,16\% daripada jumlah siswa yang menjawab opsi B yang merupakan jawaban yang benar dengan persentase sebesar 41,94\%. Terdapat 29,03\% siswa yang mampu memberikan alasan jawaban yang benar bahwa kalor dapat berpindah dari benda yang bersuhu tinggi ke benda yang bersuhu rendah, sedangkan suhu tidak dapat berpindah hanya bisa naik turun. Hasil pengkategorian alasan jawaban siswa yang salah yang sudah dikategorikan berdasarkan indikator penilaian penguasaan konsep yang berbentuk pilihan ganda beralasan pada soal nomor 1 disajikan pada tabel 2 .

Tabel 2. Persentase Pengkategorian Alasan Jawaban Siswa pada Soal Nomor 1

\begin{tabular}{clc}
\hline Alasan & \multicolumn{1}{c}{ Deskripsi } & Persentase \\
\hline 1 & Suhu dan kalor dapat berpindah dari benda Y yang memiliki suhu lebih tinggi ke benda X yang memiliki suhu lebih & $35,48 \%$ \\
& rendah & $3,23 \%$ \\
2 & Karena senyawa yang berada di dalam logam Y berpindah ke logam X & $12,90 \%$ \\
3 & $\begin{array}{l}\text { Karena suhu pada benda Y lebih besar daripada benda X, maka jika disentuhkan benda X akan menjadi panas akibat } \\
\text { suhu benda Y berpindah ke benda X. }\end{array}$ & $19,35 \%$ \\
\hline
\end{tabular}

Berdasarkan Tabel 2, diperoleh bahwa alasan jawaban siswa yang salah pada soal nomor 1 dapat dikategorikan ke dalam empat kategori. Kategori 1, 2, dan 3 merupakan kategori alasan jawaban siswa yang salah dengan jumlah persentase berturut-turut 35,48\%, 3,23\%, dan 12,90\%. Kategori 4 merupakan kategori yang tidak memberikan alasan jawaban dengan jumlah persentase sebesar 19,35\%. Hal ini menunjukkan bahwa siswa masih keliru dalam membedakan antara suhu dan kalor.

6. Benda A dan B bermassa sama dengan bentuk yang berbeda. Benda B memiliki bentuk yang lebih teratur dan keras daripada benda A. Bila kedua benda tersebut dipanaskan bersama, ternyata benda B lebih cepat panas daripada benda A. Benda yang memiliki kalor jenis paling besar adalah ....

A. B karena semakin beraturan maka semakin besar kalor jenisnya

$5(16,13 \%)$

B. A karena semakin beraturan maka semakin besar kalor jenisnya

C. B karena Benda B lebih keras daripada benda A sehingga kalor jenis B>A

D. A karena semakin lambat panas suatu benda, semakin besar kalor jenisnya*

E. B karena cepat panas suatu benda, maka semakin besar kalor jenisnya

$16(51,61 \%)$

Tidak menjawab

$0(0 \%)$

Berdasarkan soal nomor 6, diperoleh bahwa dari 31 siswa terdapat 5 siswa yang menjawab opsi A, 2 siswa yang menjawab opsi C, 8 siswa yang menjawab opsi D, 16 siswa yang menjawab opsi E, dan tidak ada siswa yang menjawab opsi A. Hal ini menunjukkan bahwa dominan siswa memilih opsi E yang merupakan jawaban yang salah dengan persentase sebesar $51,61 \%$ daripada jumlah siswa yang menjawab opsi D yang merupakan jawaban yang benar dengan persentase sebesar $25,81 \%$. Terdapat $12,90 \%$ siswa yang mampu memberikan alasan jawaban yang benar bahwa perubahan suhu suatu benda berbanding terbalik dengan kalor jenis benda tersebut. Hasil pengkategorian alasan jawaban siswa yang salah yang sudah dikategorikan berdasarkan indikator penilaian penguasaan konsep yang berbentuk pilihan ganda beralasan pada soal nomor 6 disajikan pada tabel 3. 
Tabel 3. Persentase Pengategorian Alasan Jawaban Siswa pada Soal Nomor 6

\begin{tabular}{clc}
\hline Alasan & & \multicolumn{1}{c}{ Deskripsi } \\
\hline 1 & Karena benda yang padat/keras lebih cepat panas yang disebabkan karena partikel benda yang lebih keras lebih cepat & $3,23 \%$ \\
& menyebar & $16,13 \%$ \\
2 & Karena perubahan suhu suatu benda berbanding lurus dengan kalor jenis benda tersebut & $6,45 \%$ \\
3 & Karena semakin beraturan benda tersebut, maka semakin besar kalor jenisnya & $67,74 \%$ \\
4 & Tidak memberikan alasan & \\
\hline
\end{tabular}

Berdasarkan tabel 3 diperoleh bahwa alasan jawaban siswa yang salah pada soal nomor 6 dapat dikategorikan ke dalam empat kategori. Kategori 2, 3, dan 4 merupakan kategori alasan jawaban siswa yang salah dengan jumlah persentase berturutturut $3,23 \%, 16,13 \%$, dan 6,45\%. Kategori 4 merupakan kategori yang tidak memberikan alasan jawaban dengan jumlah persentase sebesar $67,74 \%$. Hal ini menunjukkan bahwa siswa masih keliru dalam memahami hubungan antara perubahan suhu suatu benda dengan kalor jenis benda tersebut.

9. Sebuah wadah berisi air sebanyak $300 \mathrm{~g}$ yang bersuhu $80^{\circ} \mathrm{C}$, kemudian dicampur dengan cairan X sebanyak $500 \mathrm{~g}$ yang bersuhu $40{ }^{\circ} \mathrm{C}$ (asumsikan wadah tidak menyerap kalor). Jika suhu akhir campuran sebesar $55^{\circ} \mathrm{C}$, maka dapat disimpulkan ....
A. air menyerap kalor sebanyak 7500 kalori
$6(19,35 \%)$
B. air menyerap kalor sebanyak 7500 kilokalori
$9(29,03 \%)$
C. cairan X menyerap kalor sebanyak 7500 kalori*
$8(25,81 \%)$
D. cairan X menyerap kalor sebanyak 7500 kilokalori
$4(12,90 \%)$
E. air dan cairan $\mathrm{X}$ menyerap kalor sebanyak 7500 kalori
$1(3,23 \%)$
Tidak Menjawab
$3(9,68 \%)$

Berdasarkan soal nomor 9, diperoleh bahwa dari 31 siswa terdapat lima siswa yang menjawab opsi A, sembilan siswa yang menjawab opsi B, delapan siswa yang menjawab opsi C, empat siswa yang menjawab opsi D, satu siswa yang menjawab opsi E, dan tiga siswa tidak menjawab. Hal ini menunjukkan bahwa dominan siswa memilih opsi B yang merupakan jawaban yang salah dengan persentase sebesar $29,03 \%$ daripada jumlah siswa yang menjawab opsi $\mathrm{C}$ yang merupakan jawaban yang benar dengan persentase sebesar $25,81 \%$. Terdapat 3,22\% siswa yang mampu memberikan alasan jawaban yang benar bahwa suhu cairan X lebih rendah daripada suhu air, sehingga cairan X menyerap kalor dari air. Hasil pengategorian alasan jawaban siswa yang salah yang sudah dikategorikan berdasarkan indikator penilaian penguasaan konsep yang berbentuk pilihan ganda beralasan pada soal nomor 9 disajikan pada tabel 4 .

Tabel 4. Persentase Pengategorian Alasan Jawaban Siswa pada Soal Nomor 9

\begin{tabular}{clc}
\hline Alasan & \multicolumn{1}{c}{ Deskripsi } & Persentase \\
\hline 1 & Karena sudah ada keterangan jika wadah cairan X tidak menyerap kalor & $12,90 \%$ \\
2 & Karena massa dan suhu air lebih sedikit, maka menyerap suhu cairan X & $3,22 \%$ \\
3 & Karena air dan cairan X dalam perlakuan tersebut dicampurkan & $3,22 \%$ \\
4 & Tidak memberikan alasan & $77,42 \%$ \\
\hline
\end{tabular}

Berdasarkan tabel 4 diperoleh bahwa alasan jawaban siswa yang salah pada soal nomor 9 dapat dikategorikan ke dalam empat kategori. Kategori 1, 2, dan 3 merupakan kategori alasan jawaban siswa yang salah dengan jumlah persentase berturutturut $12,90 \%, 3,22 \%$, dan 3,22\%. Kategori 4 merupakan kategori siswa yang tidak memberikan alasan jawaban dengan jumlah persentase sebesar 77,42\%. Hal ini menunjukkan bahwa siswa masih kesulitan dalam memahami konsep asas Black.

11. Perhatikan grafik pemanasan $5 \mathrm{~kg}$ es berikut. Jika kalor jenis es adalah $2.100 \mathrm{~J} / \mathrm{kg}{ }^{\circ} \mathrm{C}$ dan kalor lebur es adalah $336.000 \mathrm{~J} / \mathrm{kg}$. Berapakah kalor yang dibutuhkan untuk proses dari A-B-C?

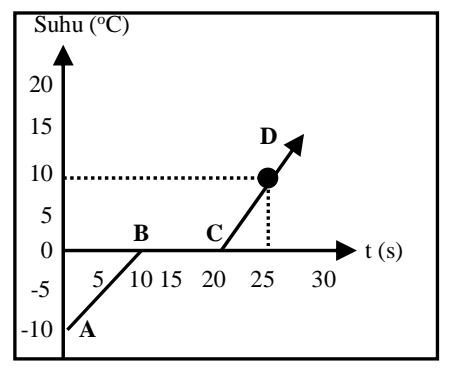
A. $2,100 \times 10^{5} \mathrm{~J}$
B. $2,310 \times 10^{5} \mathrm{~J}$
$2(6,45 \%)$
C. $1,075 \times 10^{6} \mathrm{~J}$
$6(19,35 \%)$
D. $1,680 \times 10^{6} \mathrm{~J}$
E. $1,785 \times 10^{6} \mathrm{~J}^{*}$
$9(29,03 \%)$
Tidak menjawab
$3(9,68 \%)$
$9(29,03 \%)$ 
Berdasarkan soal nomor 11, diperoleh bahwa dari 31 siswa terdapat 1 siswa yang menjawab opsi A, 2 siswa yang menjawab opsi B, 6 siswa yang menjawab opsi C, 9 siswa yang menjawab opsi D, 3 siswa yang menjawab opsi E, dan 9 siswa tidak memberikan jawaban. Hal ini menunjukkan bahwa dominan siswa memilih opsi D yang merupakan jawaban yang salah dengan persentase sebesar 29,03\% daripada jumlah siswa yang menjawab opsi E yang merupakan jawaban yang benar dengan persentase sebesar $9,68 \%$. Terdapat $6,45 \%$ siswa yang mampu memberikan alasan jawaban yang benar tentang perubahan wujud benda. Hasil pengategorian alasan jawaban siswa yang salah yang sudah dikategorikan berdasarkan indikator penilaian penguasaan konsep yang berbentuk pilihan ganda beralasan pada soal nomor 11 disajikan pada tabel 5.

Tabel 5. Persentase Pengkategorian Alasan Jawaban Siswa pada Soal Nomor 11

\begin{tabular}{|c|c|c|}
\hline Alasan & Deskripsi & Persentase \\
\hline \multirow[t]{2}{*}{1} & 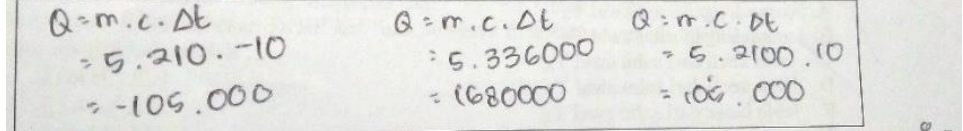 & \multirow[t]{2}{*}{$6,45 \%$} \\
\hline & Berikut ini beberapa fenomena mengenai perpindahan kalor. $\quad$ tot $a l=1,680 \times 10^{\circ} \mathrm{J}$ & \\
\hline \multirow[t]{2}{*}{2} & 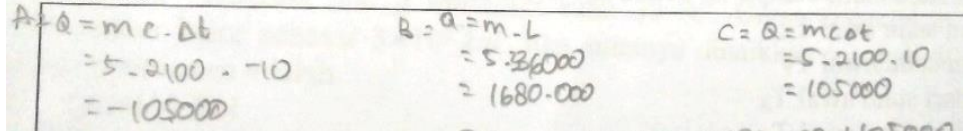 & \multirow{2}{*}{$6,45 \%$} \\
\hline & $\begin{aligned} \text { Total } & =-105000+1680.000+105000 \\
& =1.680 \times 10^{6} \mathrm{~J}\end{aligned}$ & \\
\hline 3 & $\begin{aligned} Q_{A B} & =m \cdot C \cdot D t \\
& =3 \cdot 2100 \cdot-10 \\
& =-105.000\end{aligned}$ & $9,68 \%$ \\
\hline 4 & Tidak memberikan alasan & $77,42 \%$ \\
\hline
\end{tabular}

Berdasarkan tabel 5, diperoleh bahwa alasan jawaban siswa yang salah pada soal nomor 11 dapat dikategorikan ke dalam empat kategori. Kategori 1, 2, dan 3 merupakan kategori alasan jawaban siswa yang salah dengan jumlah persentase berturut-turut $6,45 \%, 6,45 \%$, dan 9,68\%. Kategori 4 merupakan kategori siswa yang tidak memberikan alasan jawaban dengan jumlah persentase sebesar $77,42 \%$. Hal ini menunjukkan bahwa siswa masih keliru dalam memahami konsep pengaruh kalor terhadap perubahan wujud suatu benda.

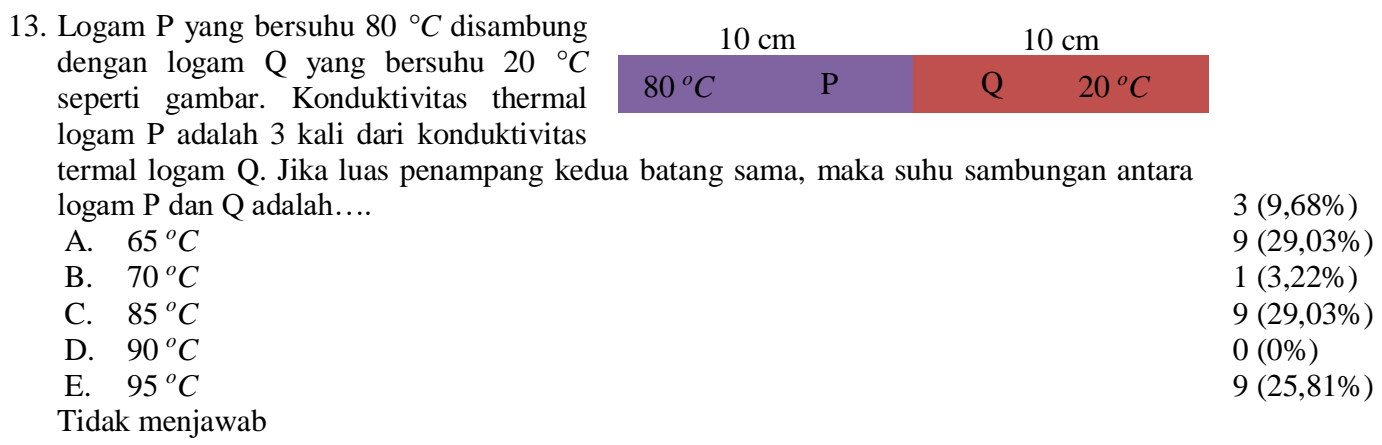

Berdasarkan soal No 13 diperoleh bahwa dari 31 siswa terdapat 3 siswa yang menjawab opsi A, 9 siswa yang menjawab opsi B, 1 siswa yang menjawab opsi C, 9 siswa yang menjawab opsi D, tidak ada siswa yang menjawab opsi D, dan 9 siswa yang tidak memberikan jawaban. Hal ini menunjukkan bahwa dominan siswa memilih opsi B dan D yang merupakan jawaban yang salah dengan persentase yang sama yaitu sebesar 29,03\%, sedangkan jumlah siswa yang memilih opsi A yang merupakan jawaban yang benar dengan persentase sebesar 9,68\%. Hasil pengategorian alasan jawaban siswa yang salah yang sudah dikategorikan berdasarkan indikator penilaian penguasaan konsep yang berbentuk pilihan ganda beralasan pada soal nomor 13 disajikan pada tabel 6.

Berdasarkan tabel 6 diperoleh bahwa alasan jawaban siswa yang salah pada soal nomor 13 dapat dikategorikan ke dalam empat kategori. Kategori 1, 2 dan 3 merupakan kategori alasan jawaban yang salah dengan jumlah persentase berturutturut $6,45 \%, 3,22 \%$, dan 3,22\%. Alasan jawaban siswa yang terdapat pada soal nomor 13 semuanya termasuk dalam kategori yang salah. Kategori 4 merupakan kategori siswa yang tidak memberikan alasan jawaban dengan jumlah persentase sebesar $87,10 \%$. Hal ini menunjukkan bahwa siswa masih mengalami kesulitan dalam memahami konsep perpindahan kalor. 
Tabel 6. Persentase Pengategorian Alasan Jawaban Siswa pada Soal Nomor 13

\begin{tabular}{|c|c|c|}
\hline Alasan & Deskripsi & Persentase \\
\hline 1 & $\begin{array}{r}T P+T_{Q} \\
2\end{array}=\frac{80+20}{2}=\frac{100}{2}=50 \rightarrow \begin{aligned} 50+2 Q \\
50+20 \\
70\end{aligned}$ & $6,45 \%$ \\
\hline 2 & $\begin{array}{l}\text { suhu logam } p=80^{\circ} \mathrm{C} \text { disambung dehgan } q=20^{\circ} \mathrm{C} \text {, suhu sambungan } \\
\text { antara } \log _{\mathrm{am}} p \text { dan } q: 80+20=100^{\circ} \mathrm{C}\end{array}$ & $3,22 \%$ \\
\hline 3 & $80+20=\frac{100}{2}=50$ karena $3 \mathrm{ko}$ & $3,22 \%$ \\
\hline 4 & Tidak memberikan alasan & $87,10 \%$ \\
\hline
\end{tabular}

\section{PEMBAHASAN}

Hasil analisis data menunjukkan bahwa penguasaan konsep suhu dan kalor siswa masih rendah, hanya 54.8\% siswa yang memiliki penguasaan konsep yang baik pada materi suhu dan kalor. Hal ini menunjukkan bahwa banyak siswa yang masih mengalami kesulitan dalam memahami konsep suhu dan kalor, sehingga menyebabkan siswa tidak memahami konsep dengan utuh. Hal serupa juga dilaporkan oleh Budiarti, et al (2017) yang menyatakan bahwa siswa masih mengalami kesulitan dalam memahami masalah yang disajikan dalam berbagai representasi, sehingga menyebabkan penguasaan konsep siswa pada materi suhu dan kalor rendah.

Berdasarkan hasil temuan, pada soal nomor 1 hanya sebanyak 29,03\% siswa yang mampu memberikan alasan ketika dua benda dengan suhu berbeda disentuhkan maka akan terjadi perpindahan kalor dari benda yang bersuhu tinggi ke benda yang bersuhu rendah. Sedangkan konsep lain yang dimiliki oleh siswa adalah: (1) suhu dan kalor merupakan besaran yang sama yang dapat berpindah dari benda yang bersuhu tinggi ke benda yang bersuhu rendah, (2) siswa menganggap bahwa yang berpindah akibat perbedaan suhu antara benda $\mathrm{Y}$ dan benda $\mathrm{X}$ adalah senyawa, dan (3) saat dua benda berbeda suhu ditempelkan, maka yang berpindah adalah suhunya. Selain itu, terdapat 19,35\% siswa yang tidak mampu memberikan alasan jawabannya, hal ini menunjukkan bahwa siswa masih mengalami kesulitan dalam membedakan antara suhu dan kalor. Kesulitan yang dialami siswa disebabkan karena ketidakmampuan siswa dalam membedakan definisi suhu dan kalor dengan benar (Alwan, 2011; Fitzallen et al., 2016; Foroushani, 2018; Kruatong et al., 2006).

Penguasaan konsep siswa pada konsep kalor jenis yang ditunjukkan pada soal nomor 6, hanya 12,90\% siswa yang mampu memberikan alasan bahwa perubahan suhu suatu benda berbanding terbaik dengan kalor jenis benda tersebut. Konsep lain yang dimiliki oleh siswa adalah: (1) benda yang padat/keras lebih cepat panas karena partikel benda lebih cepat menyebar, (2) perubahan suhu suatu benda berbanding lurus dengan kalor jenis benda tersebut, dan (3) kalor jenis suatu benda dipengaruhi oleh keteraturan atau ukuran benda tersebut. Selain itu, terdapat $67,74 \%$ siswa yang tidak mampu memberikan alasan jawabannya. Hal ini menunjukkan bahwa siswa masih mengalami kesulitan dalam memahami faktor-faktor yang dapat mempengaruhi perubahan suhu suatu benda. Siswa masih beranggapan bahwa suhu suatu benda tergantung pada ukuran benda (Budiarti et al., 2017; de Berg, 2008; Gönen \& Kokaya, 2010).

Penguasaan konsep siswa pada konsep asas Black yang ditunjukkan pada soal nomor 9, hanya 3,22\% yang mampu memberikan alasan bahwa zat cair yang menyerap kalor adalah zat cair yang memiliki suhu lebih rendah, yaitu cairan $\mathrm{X}$ dan sebaliknya cairan yang melepas kalor adalah zat cair yang memiliki suhu lebih rendah, yaitu air. Konsep lain yang dimiliki oleh siswa adalah: (1) zat cair yang memiliki massa dan suhu lebih kecil akan menyerap suhu zat cair yang memiliki suhu massa dan suhu lebih besar, (2) keterangan wadah tidak menyerap kalor pada soal dianggap bahwa cairan X yang tidak dapat menyerap kalor sehingga siswa beranggapan bahwa air yang menyerap kalor walaupun air memiliki suhu lebih besar daripada cairan X, dan (3) cairan X dan air sama-sama dapat menyerap kalor karena kedua zat cair dicampurkan. Selain itu, terdapat 77,42\% siswa yang tidak mampu memberikan alasan jawabannya. Hal ini menunjukkan bahwa siswa masih mengalami kesulitan dalam memahami konsep Asas Black yang berkaitan dengan kalor lepas dan kalor terima.

Penguasaan konsep siswa pada konsep pengaruh kalor terhadap perubahan wujud benda yang ditunjukkan pada soal nomor 11 , hanya $6,45 \%$ yang mampu memberikan alasan dalam mencari kalor total yang dibutuhkan ketika terjadi proses perubahan suhu dan perubahan wujud benda dari A-B-C, yaitu dengan menjumlahkan besarnya kalor yang dibutuhkan benda tersebut selama terjadi perubahan suhu dan perubahan wujud. Konsep lain yang dimiliki oleh siswa adalah: (1) ketika terjadi perubahan wujud juga terjadi proses perubahan suhu, sehingga dalam mencari kalor yang dibutuhkan pada proses B-C yang merupakan proses perubahan wujud siswa mengikutsertakan perubahan suhu $(\Delta T)$, (2) besarnya kalor total pada proses A-B-C 
menunjukkan bahwa terjadi tiga proses yaitu perubahan suhu (A-B), perubahan wujud (B-C), dan perubahan suhu (C-D), dan (3) perubahan suhu $(\Delta T)$ sama dengan suhu awal. Selain itu, terdapat $77,42 \%$ siswa yang tidak mampu memberikan alasan jawabannya. Hal ini menunjukkan bahwa siswa masih mengalami kesulitan dalam memahami konsep pengaruh kalor terhadap perubahan wujud suatu benda. Siswa masih beranggapan bahwa ketika suatu benda mengalami perubahan wujud, maka benda tersebut juga mengalami perubahan suhu (Maunah, 2014).

Penguasaan konsep siswa pada konsep perpindahan kalor yang ditunjukkan pada soal nomor 13, belum ada siswa yang mampu memberikan alasan yang benar dalam mencari suhu sambungan antara logam P dan Q yang memiliki suhu awal dan konduktivitas termal berbeda. Beberapa konsep yang dimiliki siswa adalah (1) suhu sambungan dua buah logam tersebut adalah nilai rata-rata suhu keduanya kemudian dijumlahkan dengan suhu logam Q, (2) suhu sambungan kedua logam tersebut adalah hasil penjumlahan dari suhu logam $\mathrm{P}$ dan $\operatorname{logam} \mathrm{Q}$, dan (3) suhu sambungan kedua logam adalah nilai rata-rata suhu logam $\mathrm{P}$ dan logam Q. Selain itu, terdapat $87,10 \%$ siswa yang tidak mampu memberikan alasan jawabannya. Hal ini menunjukkan bahwa siswa masih mengalami kesulitan dalam memahami konsep perpindahan kalor.

\section{SIMPULAN}

Berdasarkan hasil analisis dan pembahasan dapat disimpulkan bahwa penguasaan konsep siswa pada materi suhu dan kalor masih rendah, hanya terdapat $54.8 \%$ siswa yang memiliki konsep benar pada materi suhu dan kalor. Hal ini membuktikan bahwa siswa mengalami kesulitan dalam menyelesaikan permasalahan tentang suhu dan kalor. Sehingga perlu adanya perbaikan konsep yang dimiliki oleh siswa agar siswa tidak lagi mengalami kekeliruan dalam memahami konsep suhu dan kalor.

Kajian selanjutnya dapat melakukan penelitian dengan menggunakan model pembelajaran yang memberikan kesempatan kepada siswa menjadi lebih aktif dan menjadikan pembelajaran yang bermakna sehingga dapat memperbaiki penguasaan konsep siswa. Pembelajaran yang dilakukan sebaiknya dapat memperbaiki penguasaan konsep siswa melaui pembelajaran berbasis konstruktivistik. Beberapa model pembelajaran yang direkomendasikan adalah model Learning Cycle $5 E$ yang disertai dengan formative e-assessment, pembelajaran berbasis proyek terintegrasi STEM, dan Learning Cycle 5E yang terintegrasi STEM.

\section{DAFTAR RUJUKAN}

Alwan, A. A. (2011). Misconception of Heat and Temperature Among Physics Students. Procedia - Social and Behavioral Sciences, 12, 600-614. https://doi.org/10.1016/j.sbspro.2011.02.074

Baser, M. (2006). Fostering Conceptual Change by Cognitive Conflict Based Instruction on Students' Understanding of Heat and Temperature Concepts. Eurasia Journal of Mathematics, Science and Technomorlogy Education, 2(2), 96-114.

Bayrak, B. K. (2013). Using Two-Tier Test to Identify Primary Students' Conceptual Understanding and Alternative Conceptions in Acid Base. Mevlana International Journal of Education, 19-26. https://doi.org/10.13054/mije.13.21.3.2

Budiarti, I. S., Suparmi., Sarwanto., \& Harjana. (2017a). Students' Conceptual Understanding Consistency of Heat and Temperature. Journal of Physics: Conference Series, 795, 012051. https://doi.org/10.1088/1742-6596/795/1/012051

Cock, M. D. (2012). Representation Use and Strategy Choice in Physics Problem Solving. Physical Review Special TopicsPhysics Education Research, 1-15.

de Berg, K. C. (2008). The Concepts of Heat and Temperature: The Problem of Determining the Content for the Construction of an Historical Case Study which is Sensitive to Nature of Science Issues and Teaching-Learning Issues. Science \& Education, 17(1), 75-114. https://doi.org/10.1007/s11191-006-9040-z

Docktor, J. L., \& Mestre, J. P. (2014). Synthesis of Discipline-based Education Research in Physics. Physical Review Special Topics - Physics Education Research, 10(2). https://doi.org/10.1103/PhysRevSTPER.10.020119

Eraikhuemen, L., \& Ogumogu, A. E. (2014). An Assessment of Secondary School Physics Teachers Conceptual Understanding of Force and Motion in Edo South Senatorial District, 5(1), 10.

Ergin, S. (2016). The Effect of Group Work on Misconceptions of 9th Grade Students about Newton's Laws. Journal of Education and Training Studies, 4(6). https://doi.org/10.11114/jets.v4i6.1390

Ergin, S., \& Atasoy, Ş. (2013). Comparative Analysis of the Effectiveness of 4MAT Teaching Method in Removing Pupils' Physics Misconceptions of Electricity (Vol. 12).

Fitzallen, N., Wright, S., Watson, J., \& Duncan, B. (2016). Year 3 Students' Conceptions of Heat Transfer, 13.

Foroushani, S. (2018). Misconceptions in Engineering Thermodynamics: A Review. International Journal of Mechanical Engineering Education, 030641901875439. https://doi.org/10.1177/0306419018754396

Gönen, S., \& Kokaya, S. (2010). A Cross-age Study on The Understanding of Heat and Temperature. Eurasian Journal of Physics and Chemistry Education (EJPCE), 1(2), 1-15.

Gurcay, D., \& Gulbas, E. (2015). Development of Three-tier Heat, Temperature and Internal Energy Diagnostic Test. Research in Science \& Technomorlogical Education. http://dx.doi.org/10.1080/02635143.2015.1018154

Kartal, T., Öztürk, N., \& Yalvaç, H. G. (2011). Misconceptions of Science Teacher Candidates about Heat and Temperature. Procedia - Social and Behavioral Sciences, 15, 2758-2763. https://doi.org/10.1016/j.sbspro.2011.04.184

Kruatong, T., Sung-ong, S., Singh, P., \& Jones, A. (2006). Thai High School Students' Understanding of Heat and Thermodynamics. Kasetsart University Journal, 27 (2), 321, 330. 
Kulkarni, V. D., \& Tambade, P. S. (2013). Assessing The Conceptual Understanding about Heat and Thermodynamics at Undergraduate Level. European J of Physics Education, 4(2).

Madu, B. C., \& Orji, E. (2015). Effects of Cognitive Conflict Instructional Strategy on Students' Conceptual Change in Temperature and Heat. SAGE Open, 5(3), 215824401559466. https://doi.org/10.1177/2158244015594662

Maunah, N. (2014). Pengembangan Two-Tier Multiple Choice Diagnomorstic Test untuk Menganalisis Kesulitan Belajar Siswa Kelas X pada Materi Suhu dan Kalor. Inomorvasi Pendidikan Fisika, 3(2).

Sahin, M. (2010). Effects of Problem-based Learning on University Students' Epistemological Beliefs About Physics and Physics Learning and Conceptual Understanding of Newtonian Mechanics. Journal of Science Education and Technomorlogy, 19(3), 266-275. https://doi.org/10.1007/s10956-009-9198-7

Thomaz, M. F., Malaquias, I. M., Valente, M. C., \& Antunes, M. J. (1995). An Attempt to Overcome Alternative Conceptions Related to Heat and Temperature. Physics Education, 30(1), 19-26. https://doi.org/10.1088/0031-9120/30/1/004 